Article

\title{
The Impact of Fear and Authority on Islamic and Baha'i Modernisms in the Late Modern Age: A Liberal Perspective
}

\author{
Geoffrey P. Nash \\ Department of Culture, University of Sunderland, Sunderland, SR1 3PZ, UK; \\ E-Mail: geoff.nash@sunderland.ac.uk; Tel.: +44-191-515-2156 \\ Academic Editor: Todd Green
}

Received: 29 August 2015 / Accepted: 17 September 2015 / Published: 21 September 2015

\begin{abstract}
Fear of the late modern world has been a major factor in the rise of authoritarian and violent religio-political movements. This article draws on Anthony Giddens and Charles Taylor's conceptualisation of the self in the secular age, and applies this to two modernist religious trends originating in the East in the later nineteenth century in the context of western global expansion. Endeavouring to rise to the challenge of accommodating Islam to modernity by adopting the tools of rationality and encouraging independent inquiry, Islamic Modernism has become increasingly embattled. The Baha' $i$ faith, a movement that incorporates similar perspectives and also developed out of an Islamic context, proposes a theophanic transformation rather than renewal through reform of Islam. After a period of infusion of a progressive catalytic impulse into the Middle East, the Baha'i faith performed its own recalibration of modernism, enunciating apocalyptic denunciation of the modern world similar to that found in Muslim revivalist trends. The article ends by making some suggestions for continuation of a progressive religious approach in late modernity.
\end{abstract}

Keywords: self; rationalism; modernism; (neo)-traditionalism; secularity

\section{Introduction}

Fear and alienation has impacted on religious communities almost everywhere in the age of late modernity. An ever more entrenched materialism and aggressive, missionary atheism confront religion in modern societies with no obvious halt to this process in the foreseeable future. Each faith community in various ways adopts reactive responses to these tendencies and more than a few see 
today's world as a world receded from God ([1], p. 15). Tim Winter [2] discerns in some recent Muslim trends a sense of betrayal and mistrust which can go so far as denial of faith history and Islam's embodiment in past civilization. Symptoms of fundamentalist paralysis, and at worst extremist violence, characterise Muslim groups gripped by hard-line zealotry. Reactionary responses may be understandable; however they represent a serious regression from religious orientations previously founded on progressive axioms. This paper probes confluences between Islamic modernism and the Baha' $i$ faith, and asks how their respective negotiations with modernity have enabled them to shape up to the late modern world. In the discussion that follows the aim is not to demonstrate the superiority of one or other of the religious belief systems with respect to their equipment for addressing issues of modernity. Rather the major concern is to lay out the conditions of possibility whereby a progressive form of religion might operate in the late modern world.

\section{Islamic Modernism: A Response to the West}

The kind of Muslim response to "the challenge of the West" that has the aim of accommodating Islam to the modern world by means of rational thought is usually categorised by the terms "modernist", "reformist" or "modern reformist" [3-5]. The Concise Encyclopaedia of Islam more specifically qualifies the thought of the Aligarh movement and Muhammad Abduh respectively as involving "adoption of western ideas" and "appeal[ing] to those who wished to imitate the West" ([6], pp. 43, 15). Azhar Ibrahim states that modernists who emerged in the context of late colonialism in Egypt and India had as their main aim "the synthesis of Western knowledge and sciences with the best of the Islamic heritage...the early modernists' works [such as Sayyid Amir Ali's] were apologetic in nature (especially when their writings were also addressing the Western audience of the late colonial period)" ([5], p. 285). Mansour Moaddel sees Islamic modernism, starting at the end of the nineteenth century, as "the first Muslim ideological response to the Western cultural challenge" which "presented Islamic theology in a manner consistent with modern rationalist ideas" ([7], p. 2). In his introduction to Qur'anic hermeneutics, Esack ([8], p. 22) posits a battle between modernism and traditionalism in which the former demonstrates "the post-Enlightenment willingness to re-think tradition...in the light of contemporary scientific data and sociological findings; and to fuse these without necessarily specifying a commitment to do so for any social or political objectives."

Nonetheless, putting aside their frequently declared aversion to decay and stultification in traditional Islam (exacerbated by the aggressive dissemination of western-led modernity taking on specific colonial forms) the modernists' embrace of rational approaches is not without misgiving as far as their western provenance is concerned. Of the three Muslim responses to the challenge of the West adumbrated by John Esposito - rejection and withdrawal; secularism and westernization; and Islamic modernism - "Islamic modernism, like much of the modern response to the West in the twentieth century, had an ambivalent attitude toward the West, a simultaneous attraction and repulsion" ([9], p. 55). Hamid Enayat figured the modernists "urging Muslims to emulate the West in its technological and scientific achievements while condemning its moral and spiritual depravity" ([10], p. 8). Referring to Islamic education, Fazlur Rahman emphasized how "Islamic civilization confronted modern Western sciences at a multiple disadvantage — psychological as well as intellectual — because of the political domination, economic aggression, and intellectual hegemony of the West [...] the present 
Islamic conservatism is to be explained in no small measure by the colonial interregnum and the primarily psychological complications it created for the upholders of traditional education" ([11], pp. 71-72).

\section{Connections between Baha'i Leaders and Modernist Muslims}

With its roots in Babism, an early nineteenth-century movement of Iranian messianic Shi'ism, the Baha'i faith was initially considered by observers in the West as a potential manifestation of a modern religion [12]. While it is not the purpose of this article to digress on to those aspects of the shared history of Islam and the Baha'i faith which are fraught and heavily contested, it is important for purposes of comparison to establish features retained by the latter that can be considered Islamic. For example, Todd Lawson states:

The Baha'i Faith is heir to the distinctive Abrahamic cluster of myths and religious grammars or styles of piety so familiar to scholars and students of religion. The inheritance has a pronounced islamicate tonality because of the time and place in which the Baha'i Faith arose as an identifiably Iranian version of the venerable Abrahamic élan ([13], p. 463).

Referring to the imbrication of Babi-Baha'i origins in Shi' ih eschatology and prophetic history, he continues: "[this] is also Islamic in form; but, by going beyond the confines of usual Islamic belief which states there will be no prophets after Muhammad, the Baha'i Faith casts itself in the unique problematic position of being inherently Islamic in structure while being beyond the pale in actuality"1 ([13], p. 463). Indeed, in terms of its replication of prophetic authority (albeit in a revised terminology in which Prophet and Messenger are replaced by "Divine Manifestation") and insistence on the oneness of God, the Baha'i faith continues key Islamic features; moreover "other central teachings of the Baha'i Faith may have an islamicate genesis, such as the commitment to the harmony of 'science and religion', the primacy of education, the equality of men and women, the centrality of community life and so on" ([13], p. 467).

In contradistinction to frequently rehearsed, contesting narratives of persecution and apostasy, the shared religious aspects outlined above took on a positive focused character in the case of contacts between Baha'i leaders, Baha'ullah and his son Abd'ul Baha Abbas, and modernist Islamic thinkers that took place circa 1870 to 1913. Cole [14], Scharbrodt [15], and Alkan [16] have each discussed Baha'i orientations from the later nineteenth to the early twentieth century with their emphases on nostrums such as employment of reason and science, independent search for truth, toleration, and progress, and aligned these with similar developments in Islamic modernism. Cole states "although he framed his views in an apocalyptic style, Baha'u'llah's writings of the late 1860s and early 1870s brought the nascent Baha'i movement into the mainstream of modernist thought in the Middle East” ([14], p. 68). Alkan also adduces evidence for the congruence of Baha'i and Young Ottoman thought, stating "Baha'u'llah and 'Abdu'l-Baha were in contact with Ottoman reformers from the 1870s onwards" ([16], p. 261). Scharbrodt adumbrates commonalities in the positions of the Baha'i patriarch Abd'ul Baha and the Egyptian reformer Muhammad Abduh, seeing in both common

1 It is not exactly correct to call this problem unique to the Baha'i faith as Ahmadism also occupies a similar position with regard to its prophetic claims though unlike the former it still considers itself part of Islam. 
origins in "mystical and millenarian traditions of Islam", even if in their later careers "they offered contradictory responses to the perceived decline of traditional Islam" ([15], p. 13). However, Abduh's regard for mysticism rarely appeared in his writings.

Muslims and Baha'is do indeed place different emphases on modernism as regards its role in their respective communities. Muslim modernists have sought to accommodate and renew Islam by rational means (islah, ijtihad) so as to make it "fit" the modern world. Baha'is, on the other hand have often represented their religion as one that is specifically designed for modernity. For example, Cole states that Abd'ul Baha's visionary work arguing for reform of Qajar Iran, The Secret of Divine Civilization [17] can be seen as "a thoroughgoing defense of and plea for adoption of key elements of modernity, a sort of manifesto for Weberian rationalisation" ([14], p. 85). ${ }^{2}$ We can also observe in Baha'i praxis the actualisation of another Weberian concept: prophecy and the operation of charismatic leadership that "in part arises in response to social conditions of chaos and crisis" ([18], p. 40). In common with other millennial movements operating out of the Islamic world, specifically Babism and Ahmadism, the Baha' $i$ faith incorporates a prophetic dimension that is not just a supplement to rational programmes of change, but is foundational. While rationalising modern programmes can therefore be said to be shared by Muslim reformers and Baha'is alike, the latter also emphasise renewal in prophecy and charismatic leadership.

\section{Religion, the Self and Modernity}

In spite of these orientations, tensions are still raised with regard to modernity within both systems of belief, Baha'i as well as Muslim. These may be said to arise as a result of ontological disjunctions between the post-traditional order of modernity and the remainder of traditional ways of looking at the world established within both these faiths. According to the Weberian theory of secularization, "increasing human capacity to calculate and control all aspects of life without appeals either to traditional norms or charismatic enthusiasm" is accompanied by the "disenchantment of the world" ([19], p. 122). In the words of Giddens, modernity ensures "that nature, as a phenomenon external to social life, has in a certain sense come to an "end"- - as a result of its domination by human beings" ([20], p. 4). Accompanying this is an "emptying out of time and space" and a "disembedding of social institutions" ([20], p. 17) speeded up by the processes of globalisation. These in turn impact upon modernity's construction of the self-in particular the self's means of accommodating to anxieties concerning risk and trust. The resultant pressures and tensions impact at both the levels of self and the community.

The individual feels bereft and alone in a world in which she or he lacks the psychological supports and the sense of security provided by more traditional settings...

Basic trust is established in the child as part of the experiencing of a world that has coherence, continuity and dependability. Where such experiences are violated, the result can be that trust is lost, not only in other persons but in the coherence of the object world..."we have become strangers in a world in which we thought we were at home...we

2 However, as a rider Cole adds this work is also "extremely critical of other aspects of the phenomenon" of western modernity. 
cannot trust our answers to the questions "Who am I" "Where do I belong?"...with every recurrent violation of trust we become again children unsure of ourselves in an alien world" ([20], p. 34).

Giddens explores models that might compensate for this loss of trust and help the self to become better integrated into its surroundings by adopting various therapies or self-therapy. This recourse to possible agencies of help and support raises issues of choice and authority: "Living in a post-traditional order" means having access to a wider range of choices; "to act in, to engage with, a world of plural choices is to opt for alternatives, given that the signposts established by tradition now are blank" ([20], p. 82). Under a heading "Authority versus uncertainty", Giddens distinguishes between the mainly single authority that sustained the traditionalist outlook in pre-modern societies, and the diverse and uncertain "authorities" that obtain in modern ones. In pre-modern times "Religious authorities in particular quite often cultivated the feeling that individuals were surrounded by threats and dangers... Religious authority created mysteries while simultaneously claiming to have privileged access to them" ([20], p. 195). Traditional religion was thus the main resort for those seeking security in an uncertain world. In modern societies "forms of traditional authority continue to exist, including, of course, religion. Yet there is now a basic contrast with the past. Forms of traditional authority become only 'authorities' among others, part of an indefinite pluralism of expertise” ([20], p. 195).

Those seeking religious certainty to assuage fears and obtain security from threat in the modern world operate in an environment in which, Giddens points out, "modes of expertise are fuelled by the very principle of doubt". Scientific rationalism, as he makes clear early on in Modernity and Self-Identity, rather than producing solutions to questions as had first been expected by advocates of the Enlightenment, has tended to extend the parameters of doubt. Scientific method does not leave any truth inured from revision. "The integral relation between modernity and radical doubt is an issue which, once exposed to view, is not only disturbing to philosophers but is existentially troubling for ordinary individuals" ([20], p. 21; my italics). If one way of overcoming this radical doubt is to embrace the authority of religion, choosing this option - and in an ever more pluralistic world choice becomes almost unavoidable - frequently involves the exclusion of all other authorities, including alternative religious ones. This set of conditions goes some way towards explaining the situation whereby today fundamentalist forms of religion might appear more appealing than progressive ones, while at the same time being prone to conflict with one another, and in the most extreme forms, causing harm and even death to others. Boaz Huss [21], on the other hand, in shedding light on the frequently invoked term "spirituality", which he argues is a challenge to both religion and the secular, refers to a study by Robert C Fuller whose title Spiritual but not Religious: Understanding Unchurched America [22] indicates an individualised (self-help?) alternative to organised, authority-based, religion that seems partially to meet the conditions Giddens discusses.

\section{Authority versus Liberalism}

Sandwiched between traditionalist or fundamentalist religion on the one hand, and pick-and-mix syncretistic forms of belief on the other, the conditions of possibility for progressive faith may not look good in the late modern world. However some-perhaps now comparatively few-do continue to opt for liberal religious approaches, though according to Winter, that will mean "adopt[ing] the secular 
world's reductionist vocabulary for the understanding of religion...psychological, philosophical, or sociological...[to] try to show how faith, or part of it, might be recoverable even if we use these terms" ([2], p. 5). Responses to the multiplication of authorities, the deepening of uncertainty and fear, and the secularisation of society, may be disparate, but they can at the same time seem similar for followers of faiths in general, and particularly so for believers in Islam and the Baha'i faith. Regarding the struggle between tradition and reason among Muslims, Muqtedar Khan asserts:

Attempts to institutionalize and democratize the spirit of ijtihad inspire fear among the masses and incite anger, resentment, and opposition from the Ulema. The Ulema, by generating discourses that have instilled a fear of reason and independent thought, have rendered the Islamic Ummah incapable of relying on its own judgment. The Ummah seems to know only one way-Taqlid (imitation)...The condition of immaturity or jahiliyyah has become so widespread that the Ulema too, have become immature, have ceased to rely on their own rational faculties, and have surrendered the cardinal function of "judgment/reasoning" to the scholarship and religious judgement of a canonized and sacralized privileged elite from the second and third centuries of Islam ([23], p. 2).

The moment when a modern-oriented religious organisation such as the Baha'i faith began to experience its own crisis of fear of reason and independent thought can be traced to a seminar held by a group of young scholars in Cambridge, UK in summer 1978. From the late 1970s tension between a received narrative of faith history and new academic research into the Babi episode featured in the interface between scholars and the newly established Baha'i administrative order in the United States and the United Kingdom. At the same time there developed a fear of scholars and disapproval of their engagement in the new research. Khan's statement: "new scholars are appreciated as long as they are seen as revivers of the past, and those who seek to reform or institute new practices are immediately viewed with suspicion" ([23], p. 3) seemed also to apply to Baha'is who, not unlike Muslims, preferred to place emphasis on recycling authorised renditions of approved religious history. Baha'i historian Robert Stockman acknowledges that the "relationship between scholarship and a religion's institutions is often tense because scholarship investigates basic beliefs and sacred events and can arrive at conclusions that shock or discomfort administrators and believers alike... The Baha'i studies effort in Britain [and America] had a very difficult time in the...1980s" over compulsory institutional review of the work of scholars ([24], part 2, section 10). An instance of hostility arising from what was perceived as straying from this path (of re-writing official history and publishing research with the approval of the Baha'i institutional authorities) was the reception accorded to Cole's Modernity and the Millennium, a study which outside the community was considered ground-breaking in its attempt to relate the founders of the Baha'i faith to the progressive nineteenth-century thought-world in which they moved, rather than one that rehearsed the evils of the secular and religious rulers against whom they were pitted. It should be noted, however, that in this book Cole attacked the highest Baha' $i$ institution (the Universal House of Justice) in a manner that could be considered the culmination of an atmosphere of mutual mistrust and criticism between Baha'i scholars and institutions that went back to the 1970s. 


\section{Replacement of Religious Modernism}

In fact there are clear grounds for seeing the various expressions of religious modernism of the late nineteenth and early twentieth century, including Muslim and Baha'i ones as products of a period now superseded by late modernity. In his study Moslem Islam in India published in 1946, Wilfred Cantwell Smith "argued that the progressive stance of Indian Muslim liberals and modernists"-like Sayyid Ahmad Khan and Sayyid Amir Ali-“was superficial and easily reversed” ([25], p. 166, note 9). Other interpreters of Islam like Gibb [26], Hourani [27], and Tibi [28], all considered Islamic modernism as conditioned by the threat of western culture, and it might also be added, tarred by connection with it. Modernist religion having passed its watershed began to be undermined by new trends, a process we can connect to the close of 'the liberal age' which Hourani famously computed as occurring in 1939 [27]. Already in the mid-1940s, Smith considered Indian modernist Muslims to be moving toward reactionary positions such as those adopted by Abu'l Ala Maududi ([29], p. 149). This may well be connected to the decline of western colonialism. Nineteenth-century liberal religious formulations such as the Ram Mohan Roy's Brahma Samaj, Sayyid Ahmad Khan's Aligarh school of Islam, and the Ramakrishna Mission's "universal Hinduism" each flourished under the colonial umbrella in the context of Christian missionary pressure. However, at the same time colonialism incubated anti-western reformist/neo-traditionalist trends such as the Arya Samaj (formed in 1875) and much later Maududi's Jamaat-i Islami founded in 1941 ([30], pp. 366-70, 394). According to Ruthven, the latter constitutes a "systematic neo-traditionalism" whose basic premise is "Islam is entirely self-sufficient and does not need to explain itself in terms other than its own" ([4], p. 327). Writing in the mid-1940s, W.C. Smith considered Maududi symptomatic of a trend whereby: "Intelligent Indian Islam passed its social crisis and that section of it that has since been religious in the old recognizable sense, quickly became a reactionary force of very formidable proportions" ([29], p. 152).

The postcolonial age signified the nominal end of colonisation, but not the persistence of inequality of power. In its stead Islamic revivalism has emerged in the context of postcolonial reassertion of Muslim identity and under the fear/threat of the continuing encroachment of western culture. If in the 1990s some were unsure about late modernity's impact upon Islam in a world where Muslim nations were still coming to grips with the modern, the events of 9/11 and ensuing "War on Terror" led to saturation of western media by stories on Muslim extremism and failing Islamic states, aligning the Muslim world according to the spectre of an international Islamic threat. French sociologist Olivier Roy [31] presents a globalised post 9/11 Islam that, coterminous with late modernity's onslaught on traditional cultural identities, produces new de-territorialized forms comprising individuals without fixed identities who are as likely to be influenced by messages conveyed by digital media as by local mosques. According to Anoushiravan Ehteshami [32], the latest manifestation of these tendencies, ISIS/“Islamic State”, promotes a brutal pre-modern message by utilizing highly sophisticated postmodern technology. However Islam is not the only religion to take the reactionary turn. Hardline or extreme political positions have affected not just Muslims but even the most pacific of faiths, as seen in the violent and intolerant Sinhalese Buddhist group Bodu Bala Sena or the extremist Hindu nationalists attached to the Bharatiya Janata Party.

For its part, the Baha'i faith, which Cole [14] and Alkan [16] believe provided a progressive catalytic impulse towards reform in the Middle East up to the outbreak of the Great War also 
underwent its moment of recalibration of religious modernism. In 1921 Guardian of the Baha'i faith, Shoghi Effendi Rabbani, inherited leadership from his grandfather Abd'ul Baha of a tiny community scattered around the globe with huge aspirations to unite humanity in the belief that they were the bearers of the divine message to mankind. Arguing that conditions had changed, in the dark decades of the 1930s and 1940s Shoghi Effendi distanced the Baha'i outlook from the liberal platform enunciated by Abd'ul Baha on his journeys in Western Europe and the United States between 1911 and 1913. In contrast to the valorisation of reason as partner to revelation adduced by both Abd'ul Baha and Muhammad Abduh, whose encomiums on the cognate importance of reason and religion were made in the heyday of modernism, in the inter-war years Shoghi Effendi staged strong indictments against western-led civilization resonating traditional calls for repentance and the need to return to God. This culminated in the Baha'i leader's emphasis on the godless corruption of the modern age presided over by the "three false gods" of racism, nationalism and communism, setting up an apocalyptic outcome for "a world receded from [God]" ([1], p. 15).

We might argue the move from liberalism was a general feature of the inter-war years. However this was not the only reason behind the stress on apocalypse in the Baha'i faith during this period. Shoghi Effendi structured his enunciation of the same on the world's rejection of the claims of messianic authority of the founder of the Baha'i faith Baha'ullah, emphasising what Peter Smith terms the "theophanic motif" centred on the manifestation of God in a human form ([33], p. 73). ${ }^{3}$ Focussed on the teaching that a covenant existed between the believers and their divinely ordained leaders, the inclusive pattern of Abd'ul Baha's years when the Baha'i faith attracted, albeit briefly, figures like Leo Tolstoi and the Turkish reformer Abdullah Cevdet (Alkan [16]) gave way to exclusivism (Smith [33], p. 126). In the process, although great emphasis continued to be placed on world unity and the overcoming of race difference, the liberal outlook was largely sacrificed.

It is instructive to compare the alienation of the Baha'is from the modern world to the stance taken up from within Islam by Turkish-Kurd mujadid figure Bediuzzaman Said Nursi. For both, the world created by modernity through its repudiation of religion had proven itself fit for the fire, or in the words of Nursi: "This malignant civilization vomited all at once the combined savagery and crimes, all the cruelty and treachery, of former centuries, and its stomach is still queasy." Two decades before Shoghi Effendi, Nursi envisaged the future of Islam after Turkey's defeat in the Great War, elucidating "five negative principles" of "present-day civilization", included as the fourth "racialism" and "negative nationalism", which flourished "through harming others and [was] nourished through devouring others" ([34], p. 745). However, where Nursi looked to the power of the shari'a to revive the universal scope of Islam in the face of a civilization moving ever farther away from the true faith, the Baha'is were committed to a renewed covenant and message from God for mankind.

Baha'is have continued into the late modern age keeping themselves at a distance from the age's currents of corruption; at the same time dissociating themselves from active involvement with reforming social and political movements of the day, such as ones connected to peace, anti-racism or

3 I am aware that this is a very compressed overview of the development of the Baha'i faith, a religious movement that contains a varied repertoire of discourses ranging from the Sufistic early writings of Baha'ullah, through his employment of a "mirror for magistrates" style of exemplum, to his adoption of revelatory mode in his Kitab al-Aqdas, and latterly to Abd'ul Baha's modernist tafsir. 
feminism, taking what they believe to be a principled stand that these are either politically compromised or have moved beyond the spirit of the Baha'i teachings ([33], pp. 146-52). However some have seen in this a retreat into neutrality and political quietism a disengagement accompanied by a diminished adherence to the values of rationality and free inquiry which are replaced by implementation of institutional dominance above claims of the individual to free expression [35]. Emphasis on the former diminishes with the passing of the "liberal moment" and the return to doctrinal discipline that accompanied the conservative turn of the later twentieth century. Prominent Muslims and leaders of the Baha'i faith have, as emphasised above, articulated responses to modernity that amount to judgements of its alienating refusal to conform to their respective formulations of a divine order. In pointing this out it is also important to note that religious communities under stress are liable to behave in this way, when condemnation of the world provides release for tensions built up in the struggle to engage with its alienating features.

\section{Religious Progressivism and the Secular Challenge to Faith}

The challenge to faith centres on the squeezing of religion out of the public space. Such is Charles Taylor's first understanding of the meaning of the term "secularity" in the modern world. The second is "the falling off of religious belief and practice, in people turning away from God, and no longer going to Church". And thirdly: "a move from a situation where belief is unchallenged...to one in which it is understood to be one option among others, and frequently not the easiest to embrace" ([36], pp. 2-3). Together these definitions of the transformation of a religion-centred world to a secular one confirm much of what has been discussed so far. However, one of the fundamental axioms Taylor sets out to test in A Secular Age potentially links secular and progressive religious world-views. The believer juggles a two tier vision in which "human fullness" is sought in the world, but overridden by another dimension, the "transcendent", where "fullness comes from a power that is beyond me". Contrastingly, the unbeliever looks for fullness "from [...] within; and the more we realize this power, the more we become aware that $[\ldots]$ morality must be autonomous and not heteronomous" ([36], p. 10, 8). As he probes in historical terms the "lived experience" of moving from a religious to human-centred understanding of the world, Taylor's inquiry creates value for both exclusivist humanist and religious modernist positions alike. In the late Middle Ages friars and mendicants' preaching of an individual last judgement and the receding of the power of magic, creates a "new spirituality [that] had an individuating side" ([36], pp. 68-71). This built into concern with "a more personal religious life" and an "inwardness" that fed the Reformation. But whereas traditionalist and revivalist belief seems inherently hostile toward the human-centeredness, or "godlessness" of secularity, religious modernists and humanists can find common ground in this individuation as one impulse behind the development of individual conscience and ethics. Also of importance is their common attachment to "the power of cool, disengaged reason, capable of contemplating the world and human life without illusion, and of acting lucidly for the best in the interest of human flourishing" ([36], p. 9). The religious progressive may (or may not) have one over the exclusivist humanist in believing in a transcendent purpose in addition to a this-world centred one. In comparison to the confinement of the body-mind comprised self of the atheist, religious belief, Taylor thinks, can mean that boundaries stay porous enough to help individuals to find greater connection to community. Still, in building from within, both humanist and 
progressive religious approaches keep alive the Enlightenment idea of humanity's enfranchisement from tutelage through self-reflexivity, and openness to the need to find rational solutions to the world's problems. This positive aspect of modernity can be seen incorporated into modernist Muslim and Baha'i valorisation of individual inquiry and the employment of reason.

Sixty years before Taylor, W. C. Smith gave an assessment of what a progressive position in religion might be. After delineating the accommodation of their faith to modernity by prominent liberal Muslims, he stated:

...the next stage, after liberal evolution, is reached by a further recognition: that not only is human society and human life changing rapidly, but it is man himself who is effecting the change. The application of science, the product of man's own thought and activity, to industrial processes, to medicine, to war, to sociology, is changing human life into unrecognizable newness. The changes themselves mean that the old ideas of metaphysics, God, and destiny, are no longer true... Religion must not only be modern, to fit a situation which is different to-day from what it was in the twelfth, or the seventh, century. (This was the liberals' task). Religion must also be dynamic, to fit a situation which is different one minute from what it will be the next. One can better say that religion must apply not to a situation at all, but to a process. And not only must it be fluent, be prepared for changes in this process, but in so far as it is ethical, it must guide the process, it must itself determine the changes (Smith [29], p. 100, my italics).

Implicit in such a view of the effectiveness of a progressive late modern religion is the self-culturing within the believer of the practice of spiritual reflexivity; of the capacity to move from first principles towards their application in precise situations at given moments. And because time is always in movement, and circumstances changing, appeal to scriptural authority in any given situation is likely to be limiting and possibly even problematic, whether the text proffering the answer is 150 or 1350 years old. The spirit emanating from the revelation guides the will to act morally; the motivation to accomplish this comes from within; authority cannot be imposed from outside. Consensus is most important. Process is all. As for the other factor which we have been discussing, fear, this can by no means be vanquished except though courage, which provides the force to move forward, and not to retreat into the laager of scriptural literalism. ${ }^{4}$

\section{Concluding Remarks}

The liberal approach adopted in this article does not imply wholesale endorsement of modernity such as to be found in overly restrictive Weberian readings. A further extension of the arguments propounded here would certainly endorse multiple modernities (signposted for instance by thinkers like Bryan Turner) in order to ensure modern religious views are open to the global condition. The progressive approach cannot be satisfied by the abdication of reason and the embrace of authority as an antidote to fear. Most revivalist or scriptural literalist movements tend to be fixated on a single vision

4 Progressive Muslims and Baha'is have each faced issues that test the original, enfranchising spirit of revelation. For Muslims the equality of men and women has proved a sticking point between neo-traditionalism and modernism; for Baha'is, the foundational principle of toleration has come up against the proscription of homosexuality. 
variant though the detail may be. Dogmatic, fear inducing authority claims are laid down for their respective apocalyptic endgame scenarios. They cannot possibly all be right. To the contrary, nothing thrives on revision as much as prophecy. In point of fact the major orientations for a rejuvenated future for the human race are already in place. The modern world has established systems of law and justice that provide a platform for greater opportunities for human flourishing, and for building toward recognition of the unity of mankind which the major religions all inherently underwrite; the common likeness of every individual of whichever gender, race, religious or non-religious background; the justice owing to each irrespective of their social position; and the overwhelming necessity of establishing an international order upholding and arbitrating international law with respect to national disputes. All that is lacking is the belief and the will essential for the implementation of these principles.

\section{Conflicts of Interest}

The author declares no conflict of interest.

\section{References}

1. Shoghi Effendi. The Promised Day is Come. Wilmette: Baha'i Publishing Trust, 1941.

2. Tim Winter. "Muslim Loyalty and Belonging: Some reflections on the psychosocial background." In British Muslims: Loyalty and Belonging. Edited by Mohammad Siddique Seddon, Dilwar Hussain and Nadeem Malik. Leicester: The Islamic Foundation, 2002, pp. 3-22.

3. Seyyed Hossein Nasr. Traditional Islam in the Modern World. London: Kegan Paul International, 1987.

4. Malise Ruthven. Islam in the World, 2nd ed. New York: Oxford University Press, 2000.

5. Azhar Ibrahim. "Contemporary Islamic thought: A critical perspective." Islam and Christian-Muslim Relations 23 (2012): 279-94.

6. Cyril Glassé. The Concise Encyclopcedia of Islam, 3rd ed. London: Stacey International, 2008.

7. Mansour Moaddel. Islamic Modernism, Nationalism, and Fundamentalism: Episode and Discourse. Chicago: University of Chicago Press, 2005.

8. Farid Esack. The Qur'an: A User's Guide. Oxford: Oneworld, 2005.

9. John Esposito. The Islamic Threat: Myth or Reality. New York: Oxford University Press, 1995.

10. Hamid Enayat. Islam and Modern Political Thought. Austin: University of Texas Press, 1982.

11. Fazlur Rahman. Islam and Modernity: Transformation of an Intellectual Tradition. Chicago: University of Chicago Press, 1982.

12. Geoffrey Nash. "Aryan and Semite in Ernest Renan and Matthew Arnold's search for a religion of modernity." Religion and Literature 46 (2014): 25-50.

13. Todd Lawson. "Baha'i Religious History.” Journal of Religious History 36 (2012): pp. 463-70.

14. Juan R. I. Cole. Modernity and the Millennium: The Genesis of the Baha'i Faith in the Nineteenth-Century Middle East. New York: Columbia University Press, 1998.

15. Oliver Scharbrodt. Islam and the Baha'i Faith: A Comparative Study of Muhammad 'Abduh and 'Abdul-Baha 'Abbas. London: Routledge, 2008. 
16. Necati Alkan. "The Young Turks and the Baha'is in Palestine." In Late Ottoman Palestine: The Young Turk Rule. Edited by Yuval Ben-Bassat and Eyal Ginio. London: I.B. Tauris, 2011, pp. 259-78.

17. Abd'ul Baha ('Abdu'l-Baha). The Secret of Divine Civilization. Translated by Marzieh Gail. Wilmette: Baha'i Publishing Trust, 1957.

18. Seth D. Kunin. Religion: The Modern Theories. Baltimore: Johns Hopkins University Press, 2003.

19. Francis Robinson. Islam and Muslim History in South Asia. New Delhi: Oxford University Press, 2000.

20. Anthony Giddens. Modernity and Self-Identity: Self and Society in the Late Modern Age. London: Polity, 1991.

21. Boaz Huss. "Spirituality: The emergence of a new cultural category and its challenge to the religious and the secular." Journal of Contemporary Religion 29 (2014): 47-60.

22. Robert C. Fuller. Spiritual but not Religious: Understanding Unchurched America. New York: Oxford University Press, 2001.

23. Muqtedar Khan. "What is Enlightenment? An Islamic Perspective." Journal of Religion \& Society 16 (2014): 1-8.

24. Robert Stockman. The Baha'i Faith: A Guide for the Perplexed. London: Bloomsbury, 2013.

25. Geoffrey Nash. "W H Quilliam, Marmaduke Pickthall, and the window of British modernist Islam." In Postcolonialism and Islam: Theory, Literature, Culture, Society and Film. Edited by Geoffrey Nash, Kathleen Kerr-Koch and Sarah Hackett. London: Routledge, 2014, pp. 157-68.

26. Hamilton Alexander Rosskeen Gibb. Modern Trends in Islam. Chicago: Chicago University Press, 1947.

27. Albert Hourani. Arabic Thought in the Liberal Age 1798-1939. Oxford: Oxford University Press, 1962.

28. Bassam Tibi. The Crisis of Modern Islam: A Preindustrial Culture in the Scientific-Technological Age. Salt Lake City: University of Utah Press, 1988.

29. Wilfred Cantwell Smith. Modern Islam in India: A Social Analysis. London: Victor Gollanz, 1946.

30. Trevor Ling. A History of Religion East and West. London: Macmillan, 1968.

31. Olivier Roy. Globalised Islam: The Search for a New Ummah. London: Hurst, 2003.

32. Anoushiravan Ehteshami. "Regionalism in the Middle East." Talk delivered at seminar "Syria and Iraq Today: Insights to Help Our Understanding”, Durham, UK, 9 May 2015.

33. Peter Smith. The Babi and Baha'i Religions: From Messianic Shi'ism to a World Religion. Cambridge: Cambridge University Press, 1987.

34. Bediuzzaman Said Nursi. "The Gleams." In Words: On the Nature and Purposes of Man, Life, and Things. Istanbul: Sozler Publications, 2008.

35. Juan R. I. Cole. "The Genesis of the Baha'i Faith in Middle Eastern Modernity." ISIM Newsletter 2 (1999): 9.

36. Charles Taylor. A Secular Age. Cambridge: The Belknap Press of Harvard University Press, 2007.

(C) 2015 by the author; licensee MDPI, Basel, Switzerland. This article is an open access article distributed under the terms and conditions of the Creative Commons Attribution license (http://creativecommons.org/licenses/by/4.0/). 